\title{
Influence of Contaminated Crop Remains and Seed Health Quality on the Intensity of Bean Anthracnose
}

\author{
Marília G. Silva ${ }^{1}$, Edson A. Pozza ${ }^{1} \&$ José C. Machado ${ }^{1}$ \\ ${ }^{1}$ Department of Plant Pathology, Federal University of Lavras, Lavras, Brazil \\ Correspondence: Edson A. Pozza, Department of Plant Pathology, Federal University of Lavras, Lavras, Brazil. \\ Tel: 55-35-3829-1791. E-mail: edsonpozza@gmail.com
}

Received: June 13, 2013 Accepted: July 31, 2013 Online Published: September 15, 2013

doi:10.5539/jas.v5n10p56 URL: http://dx.doi.org/10.5539/jas.v5n10p56

\begin{abstract}
Bean anthracnose, caused by the fungus Colletotrichum lindemuthianum, is a major seed borne disease of beans, interfering with the progress of the disease timeline. Work involving the study of cultural remains are scarce. The effects of different incidences of that pathogen in seeds in combination with cultivating areas with and without contaminated crop remains were evaluated on the anthracnose incidence and severity and on yield. In the trial set up in December 2009 the cultivation of bean in area with contaminated crop remains had greater progress for both incidence and severity of the disease compared with the area without crop remains. There was interaction between infection levels in seeds with or without contaminated crop remains in both growing areas. In the trial set up in April 2010 progress of anthracnose was similar in both growing areas. Grain yield was higher in the area without crop remains in both trials. The results of this work showed that the behavior of anthracnose under field conditions differ among areas studied (with and without crop residues) and also due to the environmental conditions of a planting to another.
\end{abstract}

Keywords: Colletotrichum lindemuthianum, epidemiology, incidence, severity, infection levels of seed

\section{Introduction}

Common bean Phaseolus vulgaris L. is the most important species of food grain for fresh consumption in the Fabaceae family (Voysest, 2000), grown worldwide as staple food for many people (Singh, 1992). Diseases, drought and low fertility soil are limiting factors in crop yield potential in tropical and subtropical regions (Zaumeyer \& Thomas, 1957; Graham, 1978; Schwartz \& Galvez, 1980).

Most diseases are caused by fungi and they are largely spread by seeds (Richardson, 1979). Associated with seeds, fungi are the most frequent pathogens (Machado, 1994), especially species from genus Colletotrichum (anamorphic Glomerella) (Kirk et al., 2001), which are economically important organisms. In practice all agricultural crops grown around the world are susceptible to one or more species of Colletotrichum (Bailey \& Jeger, 1992). Typical symptoms of the diseases caused by those pathogens are depressed lesions where pink spore masses grow under favorable environmental conditions (Kimati et al., 1997). Colletotrichum lindemuthianum (Sacc. \& Mag), the etiological agent of bean anthracnose, can cause losses of up to $100 \%$ in the crop when contaminated seeds are planted under favorable conditions for disease progression during the crop cycle (CIAT, 1983).

As necrotrophic fungus $C$. lindemuthianum can survive from one season to another or from one crop to another as dormant mycelium inside the seed coat, and also has the ability to survive in crop remains depending on the weather conditions (Fernandez et al., 1987) and crop remains can either form or increase the primary inoculum. Seed pathogens have been developing according to different types of host-fungus interaction, which range from surface coat combinations to infection of embryo tissues. Seed infection caused by $C$. lindemuthianum in beans infects the embryo and thus those fungi can stay in seeds while they remain viable, which can ensure long survival of the pathogen (Elmer, 2001).

In general, disease begins in the crop due to the initial inoculum from crop remains or contaminated seeds (Machado, 1994), which can introduce the pathogen in disease-free areas and can also increase the inoculum in contaminated areas by consecutively use of the seeds carrying the pathogen (Baker \& Smith, 1966). From the same genus, C.graminicola is an important fungus to sorghum, as it survives in crop remains of the host plant 
during off season and in sorghum seeds as conidia and mycelium, which are both important means of spreading fungi as inoculum sources (Warren, 1986).

The anthracnose pathogen in bean seeds was first reported by Barrus in 1921 and later, a three-year crop rotation was suggested to control the fungus (Zaumeyer \& Thomas, 1957). Another seed-borne pathogen, Stenocarpella maydis is to survive saprophytically in corn crop remains by producing pycnidia and releasing conidia, and it is the major source of primary inoculum (Flett et al., 1992).

Seeds contaminated by $C$. lindemuthianum are responsible for long distance spread, whereas short distance spread occurs by splashing water from rain or irrigation. Spread of inoculum can also occur by insects, animals and man who is also an efficient means of transport of seeds and crop remains among crops, especially when operating farm equipments (Zaumeyer \& Thomas, 1957).

Bean anthracnose control is difficult because the pathogen is efficiently transmitted through seeds and able to survive for several months in soil and contaminated crop remains (Dillard \& Cobb, 1993). Based on that the association of infected seeds with different inoculum levels of $C$. lindemuthianum and contaminated crop remains has not been investigated so far. Thus, the proposal of this work was to evaluate the progress of bean anthracnose from seeds with different levels inoculum in areas with and without crop remains.

\section{Materials and Methods}

\subsection{Experimental Area and Testing Procedure}

Before installing the trials, soil samples were taken for physical and chemical analysis. Based on the results of those analyses lime requirements and optimum doses of nitrogen, phosphorus and potassium were defined. Fertilization was performed in the furrow by applying $400 \mathrm{~kg} \cdot \mathrm{ha}^{-1}$ of formulation 8-28-16 and coverage with 150 kg.ha ${ }^{-1}$ ammonium sulfate 25 days after sowing.

Two trials were installed at the farm Fazenda Palmital, Ijaci, state of Minas Gerais, latitude $21^{\circ} 09^{\prime} 43$, 56" South and longitude 44 54'56, 79" West in two growing seasons, December 2009 and April 2010. Sprinkler irrigation was performed only in the second trial $\left(40 \mathrm{~mm}\right.$ per week divided into twice). Clorpirifós $\left(480 \mathrm{~g} \cdot \mathrm{L}^{-1}\right)$ insecticide was used for pest control and weeding was removed by hand operation. Both trials were conducted in randomized complete block with four replications in factorial scheme (2x6). Factor 1 was represented by two distinct growing areas: one had a susceptible cultivar of bean crop already planted, with a final incidence of $92 \%$ anthracnose, 40 days fallow, and crop remains; the other had no crop remains and no bean plants (corn-growing area). Both areas were plowed before trial installment. Factor 2 was the six inoculum levels: Control (uninoculated seeds), $0.25 \%, 0.5 \%, 1 \%, 2 \%$ and $4 \%$ of seeds inoculated with $C$. lindemuthianum. The disease was distributed evenly in the growing area with crop remains,once the crop remains were incorporated into the area.

\subsection{Seed Origin and Inoculation Procedure}

Seeds used in this work belonged to Perola cultivar and they were free of infection by $C$. lindemuthianum according to the seed health test roll paper method described by Machado (1994).

Seeds were inoculated with $C$. lindemuthianum race 65 by the water restriction technique (Carvalho et al., 2001; Costa et al., 2003; Machado et al., 2001). Pure fungal cultures were subcultured in Petri dishes containing PDA + mannitol with water potential adjusted to $-1.0 \mathrm{MPa}$ according to MPPS Software (Michel \& Radcliffe, 1995) to inhibit seed germination. Cultures were incubated at $20^{\circ} \mathrm{C}, 12$ hour photoperiod for five days, after which the seeds were placed in contact with the fungus and incubated for four days.

\subsection{Assessment of Disease}

Ten plants were randomly selected between stages V3 and V4 in each plot for anthracnose evaluation. Eight evaluations started 19 days after sowing at intervals of seven days until pod filling at day 68 (R8 stage). Vegetative stage was assessed basing on CIAT scale (CIAT, 1983).

Incidence and severity of anthracnose in each evaluation were performed by counting the number of plants showing symptoms. Severity or percentage of infected leaf area was determined in all leaves through diagrammatic scale developed for bean anthracnose (Godoy et al., 1996).

\subsection{Disease Progress Curves}

Disease progress curves (AUDPC) for incidence (AUDPCI) and severity (AUDPCS) of anthracnose were established in the evaluation period of the experiment according Shanner \& Finey (1977). 


\subsection{Temporal Dynamics of Disease}

The area under disease curve progression (AUDPC) for severity (AUDPCS) and incidence (AUDPCI) was calculated according to Shanner \& Finey (1977) to compare treatments, and then proceeding to analysis of variance.

\subsection{Evaluation of Grain Production}

Harvest of grains in the first trial of December 2009 was done in March 2010 and grain harvest in the second trial of April 2010 was done in August 2010. In both trials the harvest was done by hand in each treatment plot. Seeds were removed from pods and weighed. Results were expressed in grams per plot.

\subsection{Climate Data}

Climate data were provided by the meteorological station of the Department of Engineering, Federal University of Lavras. Correlation between incidence of anthracnose and the variables maximum, mean and minimum temperatures, relative humidity, and precipitation was achieved with the average of data from fifteen days before assessing incidence in each trial.

\subsection{Statistical Analysis}

To perform statistical analysis of $2 \times 6$ factorial (two distinct planting areas and six inoculum levels) of the correlation analysis the SAS software (version 9.3) was used. Data were transformed to the square root of X +1 to meet the assumptions in the analysis of variance, and were performed analysis of variance of area under disease progress curve (AUDPC). When factors showed significance in the qualitative factor (areas with or without crop remains) the F-test of analysis of variance was used to differentiate the treatments. In the case of quantitative factor (inoculum levels) fitted linear regression models were fitted. When calculated, maximum and minimum were obtained from the first order derivative of the fitted regression equation.
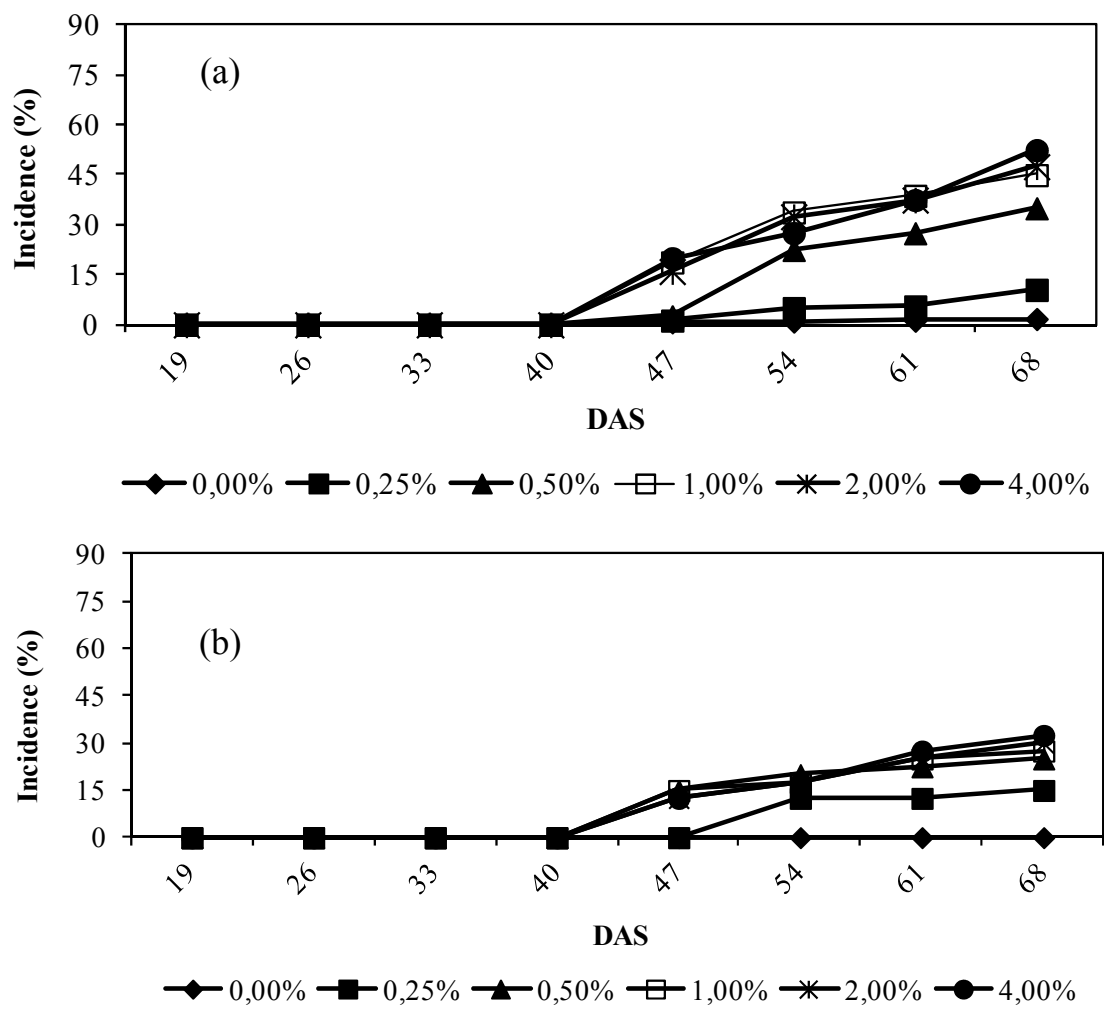

Figure 1. Progress curves of anthracnose incidence in the December 2009 trial in the area with (a) and without contaminated crop remains (b) for different seed inoculum levels 


\section{Results}

\subsection{Progress Curves of Anthracnose}

In the December 2009 trial the incidence (Figure 1) and severity (Figure 2) of anthracnose were observed 40 days after sowing (DAS) in both growing areas. From that date the disease epidemy entered its exponential phase. The area with contaminated crop remains (Figures 1a and 2a) showed greater progression for both incidence and disease severity in relation to the area without crop remains (Figures $1 \mathrm{~b}$ and $2 \mathrm{~b}$ ). To level $0 \%$ of infection (uninoculated seeds) the disease was observed only in the area with crop remains. In the area without crop remains the maximum incidence was 32.50 and maximum severity $6.3 \%$, while in the area with contaminated crop remains the values were 52.50 and $8.6 \%$ respectively.
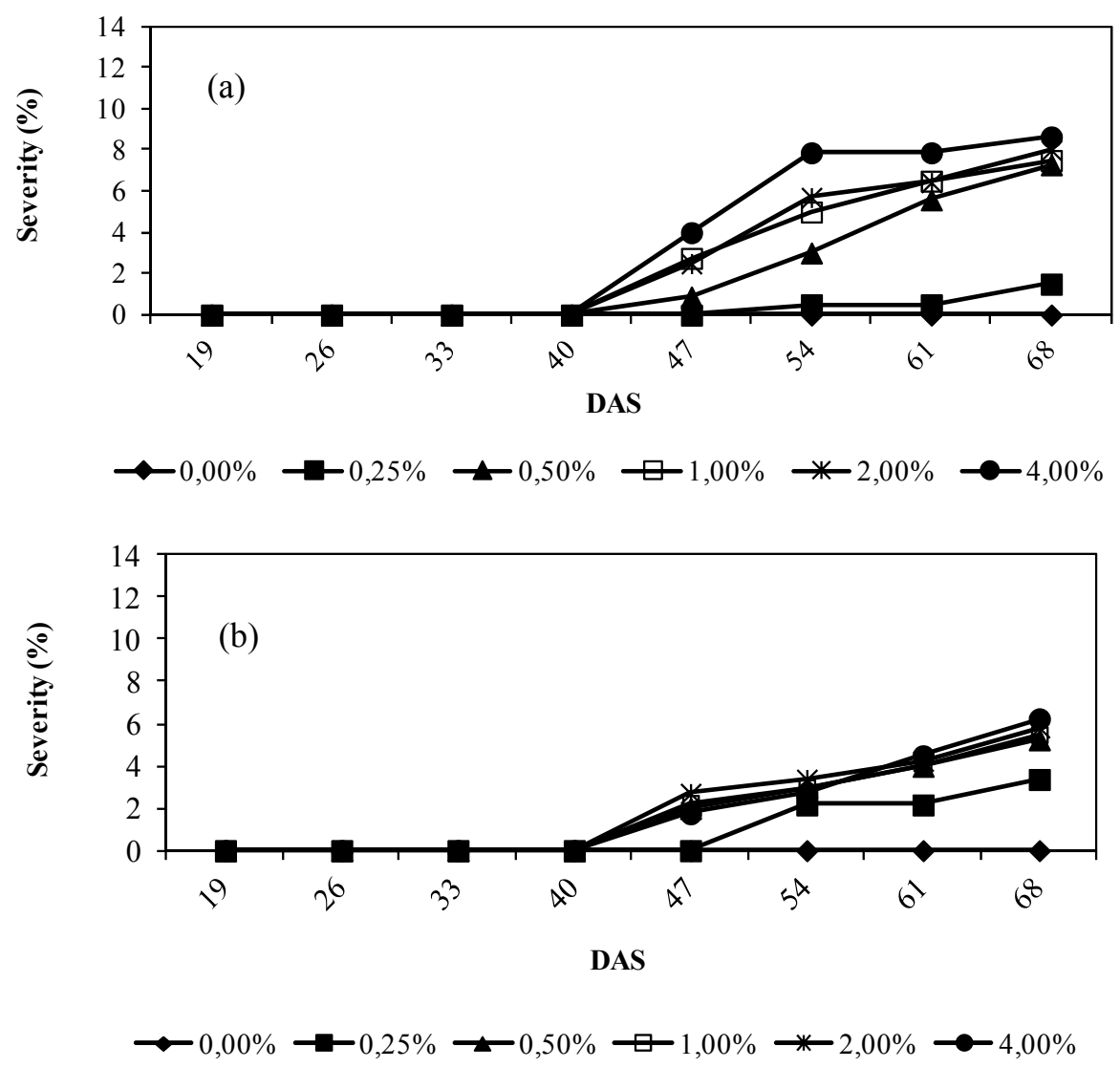

Figure 2. Progress curves of anthracnose severity in the December 2009 trial in the area with (a) and without contaminated crop remains (b) for different seed inoculum levels

In the April 2010 trial both incidence (Figure 3) and severity (Figure 4) of disease were observed 40 days after sowing in both growing areas, when the exponential phase of the disease progression started. Progress of incidence and severity was similar in both growing areas (with and without crop remains). To level $0 \%$ of infection (uninoculated seeds) the disease was observed only in the area with crop remains. In the area without crop remains the maximum incidence of anthracnose was $80 \%$ and maximum severity $12 \%$, while in the area with crop remains the values were $82.50 \%$ and $13 \%$ respectively. 

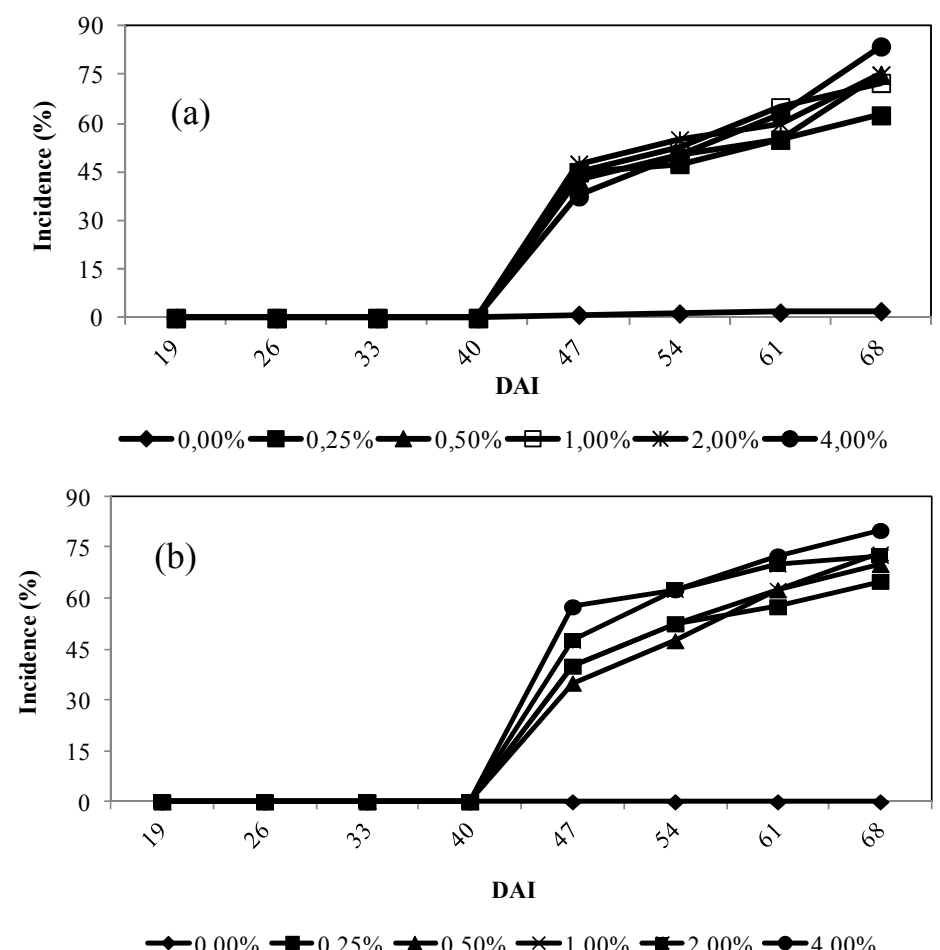

Figure 3. Progress curves of anthracnose incidence in the April 2010 trial in the area with (a) and without contaminated crop remains (b) for different seed inoculum levels
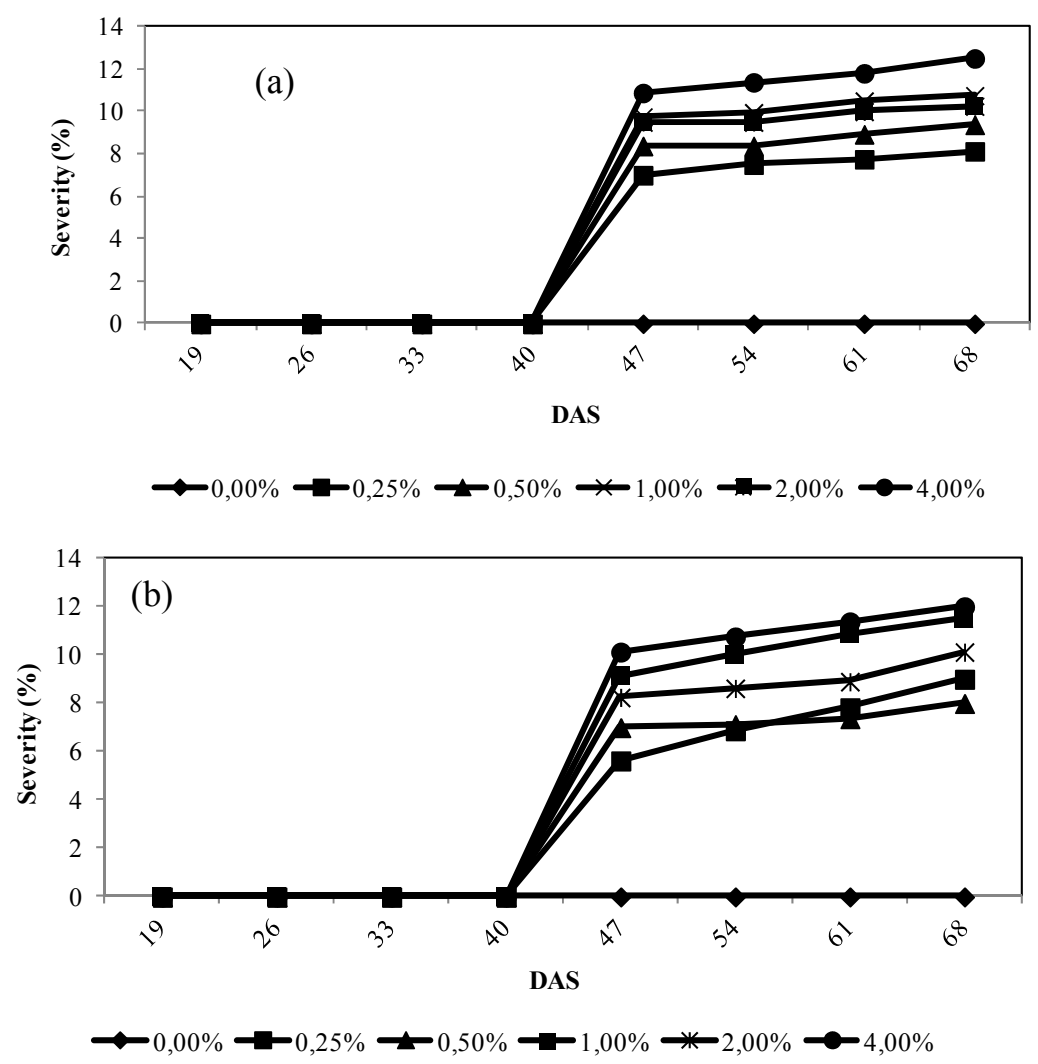

Figure 4. Progress curves of anthracnose severity in the April 2010 trial in the area with (a) and without contaminated crop remains (b) for different seed inoculum levels 


\subsection{Disease Incidence and Environmental Variables}

During the crop cycle in the December 2009 trial the average temperature was $23.7^{\circ} \mathrm{C}$, higher than the optimum for bean anthracnose development. According to Schwartz et al. (2005), plant infection is favored by temperatures $13-26^{\circ} \mathrm{C}$, the optimum being $17^{\circ} \mathrm{C}$. Although the trial was set up in a rainy season the relative humidity average was $72 \%$, which is lower than the disease requirements, i.e. humidity above $92 \%$ (Schwartz et al., 2005). Thus, these factors contributed to low disease incidence in the experiment.

In the April 2010 trial the mean temperature was $17.4{ }^{\circ} \mathrm{C}$ thus favorable to disease during crop cycle. Associated with sprinkler irrigation, temperature increased disease incidence.

\subsection{AUDPC for Incidence (AUDPCI) and Severity (AUDPCS)}

There was significant interaction between inoculum levels and growing area for AUDPCI in the December 2009 trial. The areas with and without crop remains showed the highest incidence at levels $1.27 \%$ and $1.11 \%$ inoculum, respectively (Figure 5). The highest AUDPCI was achieved in the area with crop remains.
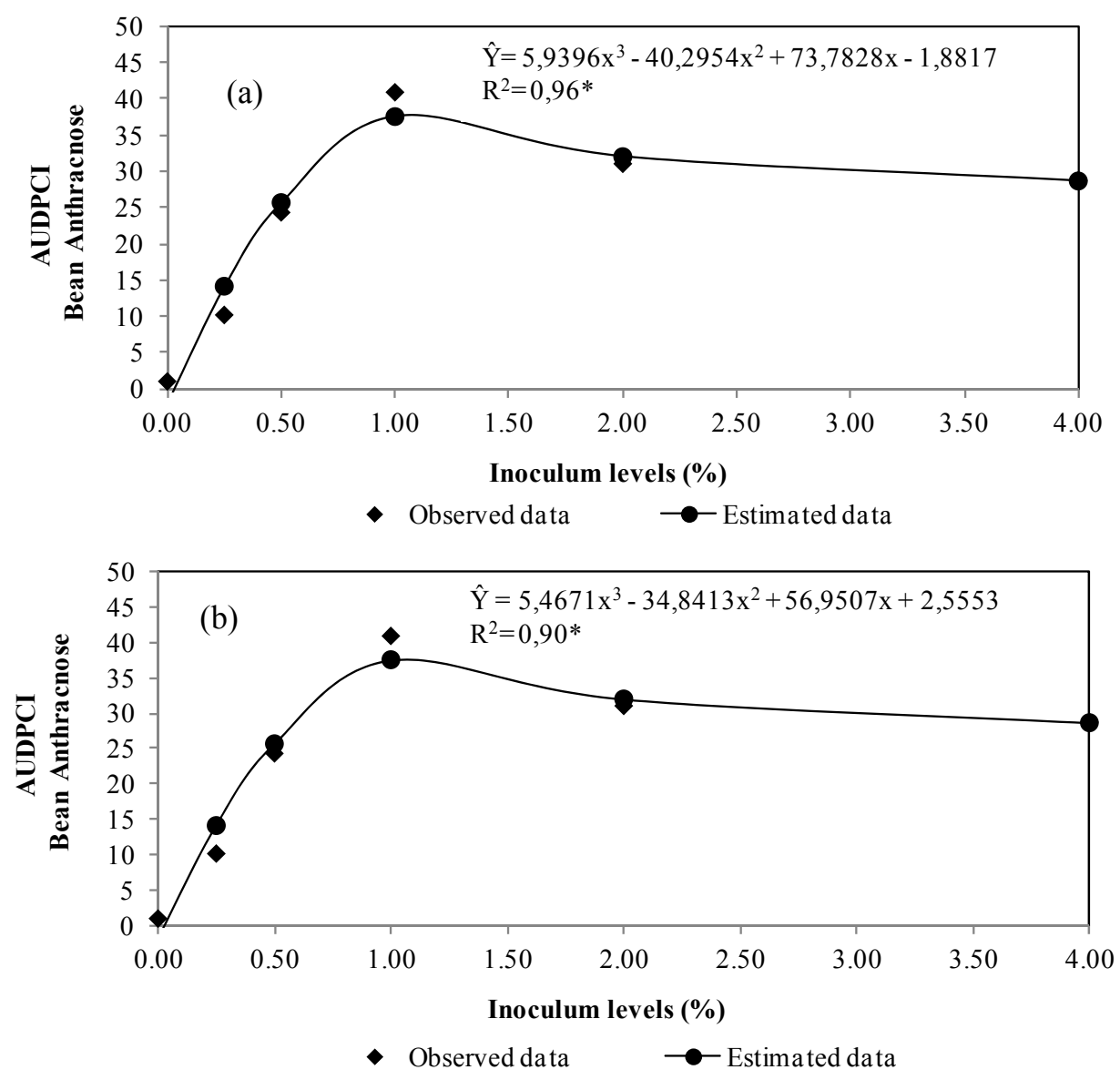

Figure 5. Area under disease progress curve for anthracnose incidence (AUDPCI) in the December 2009 trial. Increasing inoculum levels in relation to growing areas with (a) and without contaminated crop remains (b)

There was also a significant interaction between inoculum levels and growing area for AUDPCS in the December 2009 trial. In the areas with and without crop remains, severity was higher at levels $1.62 \%$ and $1.00 \%$ inoculum, respectively (Figure 6). The highest severity level was also found in the area with crop remains. 


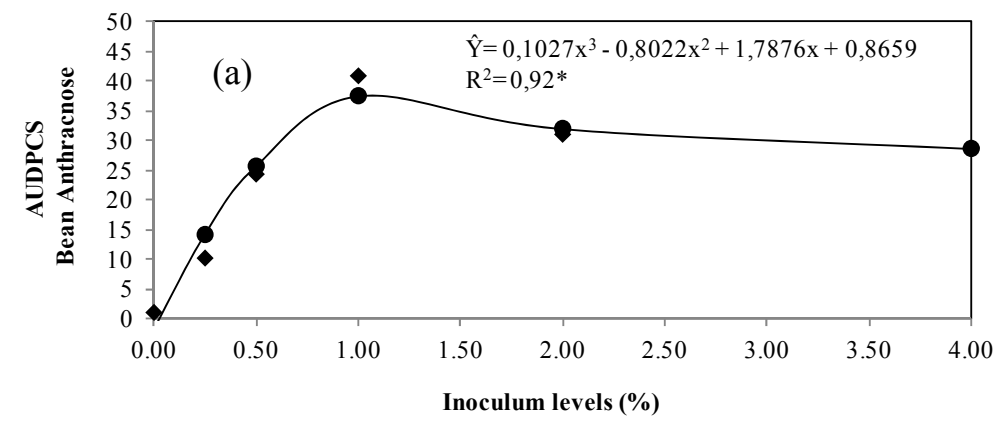

- Observed data $\rightarrow$ Estimated data

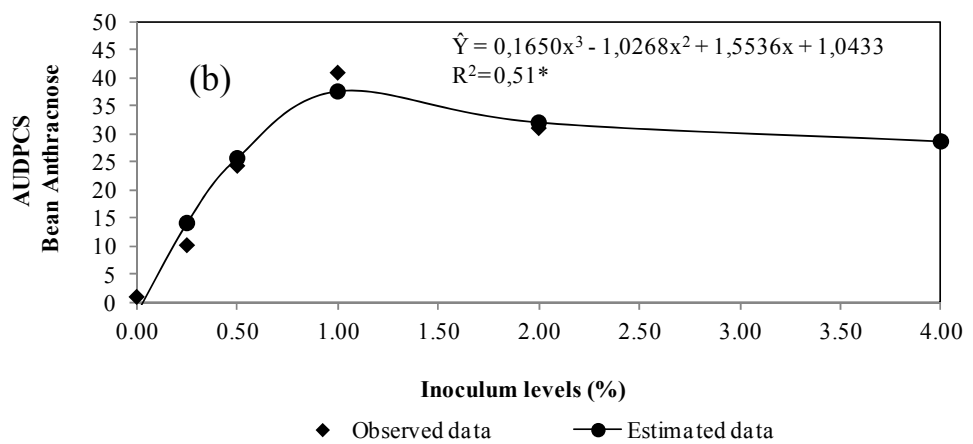

Figure 6. Area under disease progress curve for anthracnose severity (AUDPCS) in the December 2009 trial.Increasing inoculum levels in relation to growing areas with (a) and without contaminated crop remains (b)

The April 2010 trial also showed significant interaction between inoculum levels and growing area for AUDPCI (Figure 7), however, there was no significant difference between growing areas. In the areas with and without crop remains the highest incidence occurred at levels $1.16 \%$ and $1.19 \%$ inoculum, respectively.
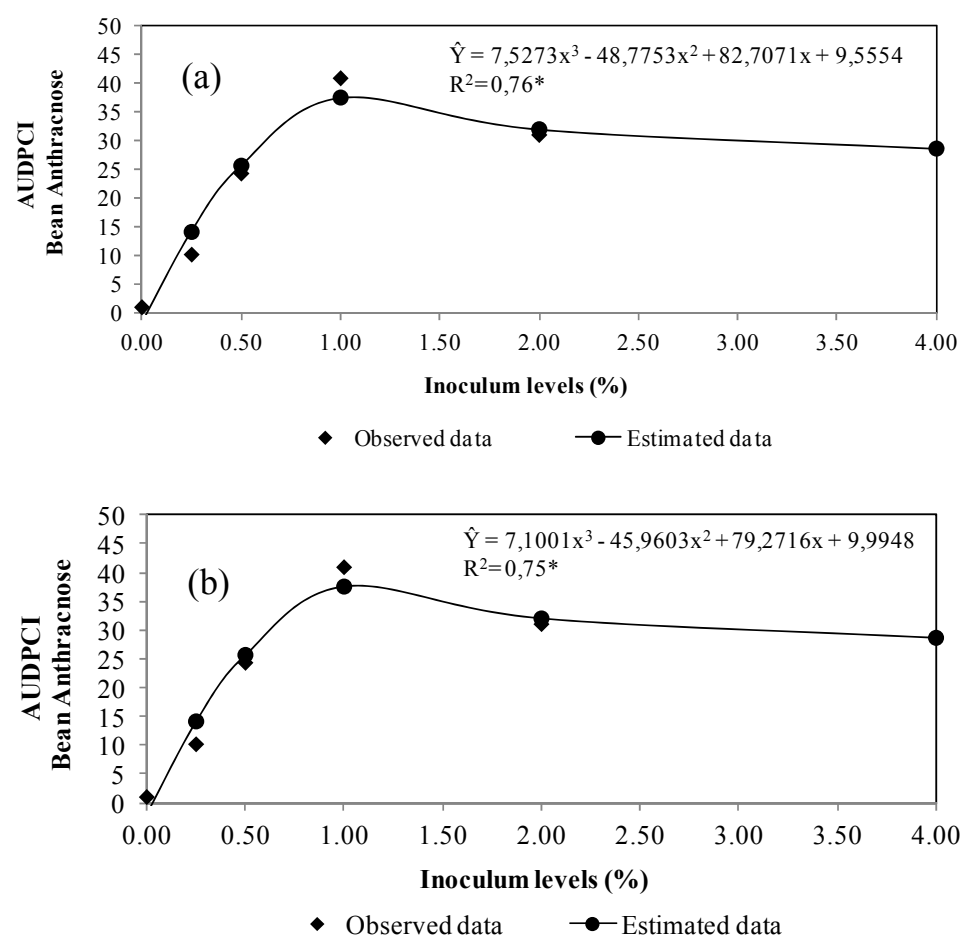

Figure 7. Area under disease progress curve for anthracnose incidence (AUDPCI) in the April 2010 trial.Increasing inoculum levels in relation to growing areas with (a) and without contaminated crop remains (b) 
As regards to severity, there was a significant difference between the various inoculum levels and growing areas, however, the interaction was not significant. The highest severity was at level 1.19\% inoculum (Figure 8). There were significant differences between areas, however, and the highest severity level was found in the area with crop remains.

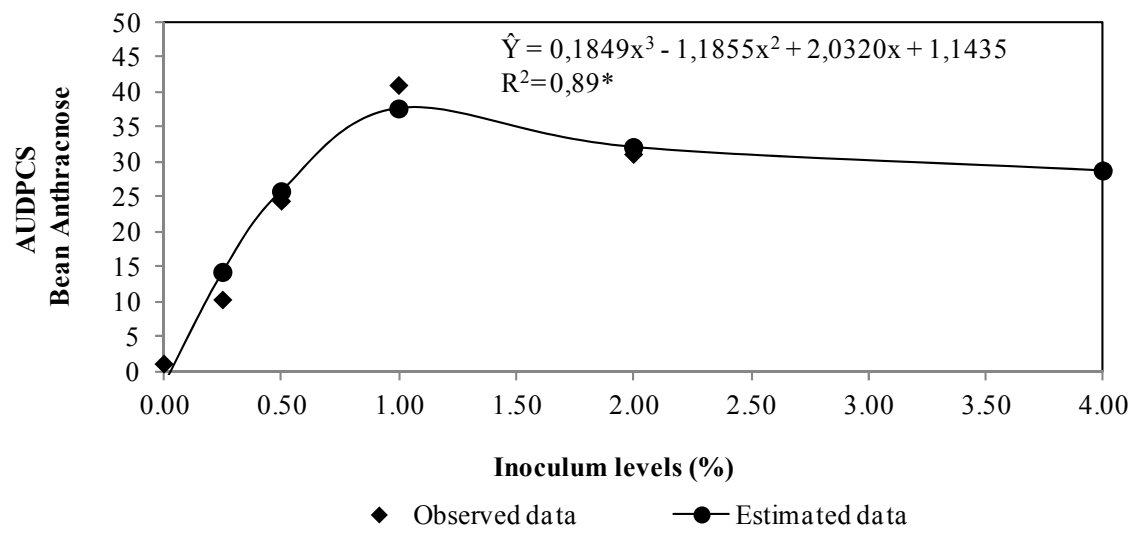

Figure 8. Area under disease progress curve for anthracnose severity (AUDPCS) in inoculum levels in April trial

\subsection{Analysis of Grain Production}

According to the statistical analysis of production, growing area was significant in the December 2009 trial. Crop yield was $240 \mathrm{~kg} \cdot \mathrm{ha}^{-1}$ in the area with crop remains while the area without crop remains produced 936 $\mathrm{kg} \cdot \mathrm{ha}^{-1}$. There was no significant interference of inoculum levels with crop production.

Neither inoculum levels nor growing areas showed significant interaction in the April 2010 trial. However, there was significant influence separately on grain production in relation to growing area and inoculum levels. Production was $290 \mathrm{~kg} \cdot \mathrm{ha}^{-1}$ in the area with crop remains and $858 \mathrm{~kg} \cdot \mathrm{ha}^{-1}$ in the area without crop remains. The highest yield obtained by linear regression analysis was at level zero (control) and the lowest at $3.60 \%$, near the maximum inoculum level evaluated in our experiment.

\section{Discussion}

The area with crop remains in the December 2009 trial showed the highest inoculum levels and greater progress in both incidence and severity of disease in relation to the area without crop remains. The previous crop was harvested 40 days before the experiment thus in the range of survival of $C$. lindemuthianum in plant crop remains, ranging from six months to about two years (Fernandez et al., 1987). Hence, higher intensity of anthracnose in the area with crop remains was due to larger amount of initial inoculum from the previous crop where $C$. lindemuthianum survived (Fernandez et al., 1987). As a large number of primary sources of inoculum can increase the number of diseased plants, crop remains should be deemed capable of interfering in disease progress in space and time. Incidence of diseased plants and grains infected by $S$. maydis in no-till corn crops was higher than in areas of conventional tillage (Flett \& Wehner, 1991).

In addition, the area with crop remains showed higher AUDPCI and AUDPCS values in relation to the area without remains. For the area with crop residues, the AACPDI was $37 \%$ higher than the area without crop residues and AACPDS, this difference was $42 \%$, which confirms the hypothesis that crop remains influence the progression of disease as source of inoculum, since synergy occurs between amount of contaminated seeds and inoculum, and pathogen transmission ( $\mathrm{Tu}, 1983,1992)$. Moreover, seeds are the main vehicle for pathogen spread over long distances (Neergaard, 1979). These results showed a close relationship between disease severity in the field and amount of inoculum on seed surface. If the environment is favorable to the epidemic, disease progression can be faster. Further, the higher the pathogen incidence in seeds, the higher the percentage of outbreaks in the growing area (Maffia et al., 1988).

The April 2010 trial showed similar progress of incidence and severity in both growing areas (with and without crop remains). Temperature was favorable to the pathogen during crop cycle, and disease progression was higher compared with the previous crop. The AACPDI in the area with debris was $12 \%$ higher than the area without crop residues and the AACPDS was $9 \%$ higher than the area without crop residues. Additionally, sprinkler irrigation at constant intervals may have contributed to further progression of disease because spore germination 
and spread also increased (Bailey et al., 1992), as the pathogen requires relative humidity above $92 \%$ (Schwartz et al., 2005). With regard to spatial expansion of $C$. lindemuthianum from an inoculum source, Pinto et al. (2001) from Lavras, state of Minas Gerais, found significant difference in AUDPC between two planting seasons. Studies by Garcia et al. (2007) also showed differences in incidence and severity of disease depending on the season. These results can be attributed to favorable climatic conditions for supporting the pathogen.

Observed that increasing levels of seed inoculated with $C$. lindemuthianum provided the highest rates for disease progression, which were similar to results obtained by Talamini (2003). However, the author evaluated different planting periods and did not include the study of crop remains in the experiment.

AUDPCI values differed in relation to inoculum levels in both growing areas. The highest incidence rates were found in plots planted with infected seed, even at low values such as $0.25 \%$. Talamini (2003) detected differences between inoculum levels for disease incidence (AUDPCI). Levels $0 \%, 0.5 \%$ and $1.0 \%$ infected seeds differed and had lower AUDPCI values at levels $2.0 \%$ and $4.0 \%$. These results show that disease incidence tends to increase with large amounts of initial inoculum. In another experiment conducted in the region Zona da Mata, Minas Gerais, Brazil, Pereira et al. (2002) found higher incidence of anthracnose in seeds with inoculum level $3.8 \%$ when compared with the control, which was free from infected seeds.

In the state of Rio Grande do Sul, Krieger et al. (2005) did not observe occurrence of anthracnose in a December planting. This outcome is possibly associated with reduction and/or elimination of the primary inoculum source (Madden et al., 2008) consisting of seeds and contaminated crop remains, as the experiment used certified seeds with low incidence of $C$. lindemuthianum treated with specific fungicides and sown in rotation area without bean straw. According to Machado et al. (2002), seeds infected or contaminated with pathogens are responsible for the perpetuation, introduction and spread of many diseases of the world's major crops.

In this experiment found a significant influence of crop remains in relation to the area without crop remains and the amount of inoculum in seeds, which affected grain production in both crops. Thus, in the growing area where disease intensity was higher (area with contaminated crop remains) grain yield was lower. Also found that bean crop remains interfere with both incidence and severity of anthracnose, and the higher the level of inoculum in seeds under favorable environmental conditions, the higher the disease progression and thus the lower the yield. Similar results were obtained by Garcia et al. (2007) in the same region with significant negative correlation of anthracnose severity with grain yield. High severity levels in most bean growing seasons were deemed a risk factor affecting crop yield. Pompeu et al. (1992) also highlighted the importance of anthracnose, as it constantly occurs in various planting seasons and thus reduces crop yield. In contrast, Nunes and Bergamin Filho (1996) found no correlation between disease severity and yield in bean cultivars Carioca and Rosinha in the seasons under study, probably due to varied characteristics of the experimental areas. Neither did Talamini (2003) find any significant correlation between AUDPCI and AUDPCS with bean yield in two planting seasons in Lavras, state of Minas Gerais, with bean cultivar Carioca. A possible reason could be evaluation of disease based only on remaining leaves, as anthracnose causes defoliation and the amount of disease could have been underestimated in that case.

There is certainly a need for further studies on pathogens that survive in contaminated crop remains, due to their potential ability to cause epidemics in growing areas and consequently production losses.

\section{Acknowledgements}

The authors would like to thank CNPq (National Council for Technological and Scientific Development), CAPES (Coordination for Improvement of Superior Level Personnel) and FAPEMIG (Minas Gerais State Research Foundation) for their financial support. The first author would also like to thank CNPq for granting her a scholarship.

\section{References}

Bailey, J. A., \& Jeger, M. J. (1992). Colletotrichum: Biology, Pathology and Control. CAB International, UK: Wallingford.

Bailey, J. A., O’Connel, R. J., Pring, R. J., \& Nash, C. (1992). Infection strategies of Colletotrichum species. In: J. A. Bailey, \& M. J. Jeger (Eds.), Colletotrichum: Biology, Pathology and Control (pp. 88-120). CAB International, UK: Wallingford.

Baker, K. F., \& Smith, S. H. (1966). Dynamics of seed transmission of plant pathogens. Annual Review of Phytopathology, (4), 311-334. http://dx.doi.org/10.1146/annurev.py.04.090166.001523

Barrus, M. F. (1921). Bean anthracnose. Cornell University Agricultural Experiment Station, NY: Ithaca. 
Carvalho, J. C. B., Machado, J. C., \& Vieira, G. M. (2001). Crescimento micelial de Colletotrichum lindemuthianum em relação à restrição hídrica do substrato agarizado. Ciência e Agrotecnologia, 25(4), 999-1005.

Costa, M. L. N., Machado, J. C., Guimaraes, R. M., Pozza, E. A., \& Oride, D. (2003). Inoculation of bean seeds with Fusarium oxysporum f. sp. phaseoli through water restriction technique. Ciência e Agrotecnologia, 27(5), 1023-1030. http://dx.doi.org/10.1590/S1413-70542003000500008

Dillard, H. R., \& Cobb, A.C. (1993). Survival of Colletotrichum lindemuthianum in bean debris in New York State. Plant Dis., (77), 1233-1238. http://dx.doi.org/10.1094/PD-77-1233

Elmer, W. H. (2001). Seeds as vehicles for pathogen importation. Biological Invasions, (3), $263-271$. http://dx.doi.org/10.1023/A:1015217308477

Fernandez, C. M. A., Dhingra, O. D., \& Kushalappa, A. C. (1987). Influence of primary inoculum on bean anthracnose prevalence. Seed Sc. Technology, 15(1), 45-54.

Flett, B. C., \& Wehner, F. C. (1991). Incidence of Stenocarpella and Fusarium cob rots in monoculture maize under different tillage systems. J. of Phytopath., 133(4), $327-333$. http://dx.doi.org/10.1111/j.1439-0434.1991.tb00168.x

Flett, B. C., Wehner, F. C., \& Smith, M. F. (1992). Relationship between maize stuble placement in soil and survival of Stenocarpella maydis (Diplodia maydis). J. of Phytopath., 134(1), 33-38. http://dx.doi.org/10.1111/j.1439-0434.1992.tb01210.x

Garcia, A., Souza, P. E., Pozza, E. A., \& Santos, F. S. (2007). Influência das variáveis ambientais no progresso da antracnose do feijoeiro e eficiência de tiofanato metílico + clorotalonil no controle da doença. Ciência e Agrotecnologia, 31(6), 1709-1715. http://dx.doi.org/10.1590/S1413-70542007000600016

Godoy, C. V., Carneiro, S. M. T. P. G., Iamauti, M. T., Pria, M. D., Amorim, L., Berger, R. D., \& Bergamin Filho, A. (1996). Diagrammatic scales for bean diseases: development and validation. J. of Plant Dis. and Prot., 104(4), 336-345.

Graham, P. H. (1978). Some problems and potentials of field beans (Phaseolus vulgaris L.) in Latin America. Field Crops Res., 1(4), 295-317. http://dx.doi.org/10.1016/0378-4290(78)90033-3

International Center For Tropical Agriculture. (1983). Etapas de desarollo de la planta de frijol común. Guia de Estudio, Cali, Columbia.

Kimati, H., Bergamin Filho, A., \& Amorin, L. (1997). Manual de fitopatologia: doenças das plantas cultivadas. São Paulo, SP.

Kirk, P. M., Cannon, P. F., David, J. C., \& Stalpers, J. A. (2001). Dictionary of Fungi. Wallingford: CABI Bioscience.

Krieger, I., Casa, R. T., Moreira, E. N., Rizzi, F., \& Kuhnem, P. R. (2005). Critérios para aplicação de fungicidas visando o controle de doenças foliares do feijoeiro comum. In Reunião Técnica Catarinense de Milho e Feijão (pp.311-314). Santa Catarina.

Machado, J. C. (1994). Padrões de tolerância a patógenos associados à semente. In: Revisão anual de patologia de plantas (pp. 229-263). Passo Fundo.

Machado, J. C., Langerak, C. J., \& Jaccoud Filho, D. S. (2002). Seed-Borne Fungi: A Contribuition to Routine Seed Health Analysis. International Seed Testing Association.

Machado, J. C., Oliveira, J. A., Vieira, M. G. G. C., \& Alves, M. C. (2001). Inoculação artificial de sementes de soja por fungos utilizando solução de manitol. Revista Brasileira de Sementes, 23(2), 95-101.

Madden, L. V., Hugles, G., \& van den Bosch, F. (2008). The Study of Plant Disease Epidemics. St. Paul, MN.

Maffia, L. A., Muchovej, J. J., \& Maffia, A. M. C. (1988). Fundamentos epidemiológicos no estudo da transmissão de patógenos por sementes. In: Simpósio Brasileiro de Patologia de Sementes (pp. 41-47). Lavras.

Michel, B. E., \& Radcliffe, D. (1995). A computer program relating solute potencial to solution composition for five solutes. Agronomy J., 87, 131-136. http://dx.doi.org/10.2134/agronj1995.00021962008700010022x

Neergaard, P. (1979). Seed pathology. London, UK, MacMillan.

Nunes, W. M. C., \& Bergamin Filho, A. (1996). Avaliação dos danos causados pela antracnose (Colletotrichum lindemuthianum) do feijoeiro. Fitopatologia Brasileira, 21(4), 436-442. 
Pereira, J. M., Pinto, C. M. F., Dhingra, O. D., \& Faria, R. F. (2002). Influência de sementes infectadas por Colletotrichum lindemuthianum na incidência da antracnose e na produtividade do feijoeiro. In Congresso Nacional de Pesquisa de Feijão (pp. 153-155). Viçosa.

Pinto, A. C. S., Pozza, E. A., Talamini, V., Machado, J. C., Sales, N. L. P., Garcia Júnior, D., \& Santos, D. M. (2001). Análise do padrão espacial e do gradiente da antracnose do feijoeiro em duas épocas de cultivo. Summa Phytopathologica, 27(4), 392-398.

Pompeu, S. S., Dudienas, C., \& Ito, M. F. (1992). Linhagens de feijoeiro resistentes ao fungo da antracnose (Colletotrichum lindemuthianum), obtidas pelo uso dos genes Mex2 e Mex3. Summa Phythopatol., 18(3), 220-226.

Richardson, M. J. (1979). An annotated list of seed-borne diseases. Kew: Commonwalth Mycological Institute, Phytopathological Papers 23.

Schwartz, H. F., \& Galvez, G. E. (1980). Beans production problems: disease, insect, soil and climatic constrains of Phaseolus vulgaris. CIAT, Cali, Colombia.

Schwartz, H. F., Steadman, J. R., Hall, R., \& Forster, R. L. (2005). Compendium of Bean Disease (2nd ed.). St. Paul: Minnesota.

Shaner, G., \& Finney, R. E. (1977). The effect of nitrogen fertilization on the expression of slow-mildewingresistance in knox wheat. Phytopathology, 67, 1051-1056. http://dx.doi.org/10.1094/Phyto-67-1051

Singh, P. S. (1992). Common bean Improvement in the Tropics. Plant Breeding Reviews, 10, 199-269.

Talamini, V. (2003). Progresso espacial e temporal da antracnose a partir de diferentes níveis de inóculo inicial em sementes de feijoeiro. PhD thesis, Universidade Federal de Lavras, Lavras.

Tu, J. C. (1983). Anthracnose (Colletotrichum lindemuthianum) on white bean (Phaseolus vulgaris) in southern Ontario: survival of the pathogen. Plant Dis., 67, 402-404. http://dx.doi.org/10.1094/PD-67-402

Tu, J. C. (1992). Colletotrichum lindemuthianum on Bean: Population dinamics of the pathogen and breeding for resistance. In: Bailey, J. A., \& Jeger, M. J. (Eds.), Colletotrichum: Biology, pathology and control (pp. 203-224). CAB International Wallingford, UK.

Voysest, O. V. (2000). Mejoramiento genetico del frijol (Phaseolus vulgaris) legado de variedades de América Latina. CIAT, Cali, Colombia.

Warren, H. L. (1986). Leaf anthracnose. In Frederiksen, R. A. (Ed.), Compendium of Sorghum Diseases (pp. 10-11). St. Paul: Minnesota.

Zaumeyer, W. J., \& Thomas, H. R. (1957). A monographic study of bean diseases and methods of their control. Washington: USDA (Technical Bulletin, 868).

\section{Copyrights}

Copyright for this article is retained by the author(s), with first publication rights granted to the journal.

This is an open-access article distributed under the terms and conditions of the Creative Commons Attribution license (http://creativecommons.org/licenses/by/3.0/). 